\title{
Analisis Faktor-faktor yang Mempengaruhi Produktivitas Kerja Karyawan di PT. Multi Terminal Indonesia
}

\author{
RETNO AYU HASTUTI \\ TRI BODROASTUTI \\ TANTRI WIDIASTUTI \\ Sekolah Tinggi Ilmu Ekonomi Widya Manggala Semarang \\ Jalan Sriwijaya No. 32 \& 36 Semarang 504242 \\ Email : retnoayuhastuti96@gmail.com
}

Diterima 1 September 2021; disetujui 10 September 2021;

\begin{abstract}
Work productivity is the ability to carry out activities that produce an output or work in accordance with the quality set, but often there are obstacles that cause the company's goals to be less achieved. Every company has a different policy on efficient sourcing. The purpose of this study was to determine and analyze how the effect of knowledge, skills, abilities, attitudes and behavior on work productivity of PT. Multi Terminal Indonesia. The population in this study were 30 employees and the entire population was sampled. The analytical tool used in this research was Multiple Linear Regression Analysis. The results showed that knowledge $\left(X_{1}\right)$, skills $\left(X_{2}\right)$ abilities $\left(X_{3}\right)$, behaviors $\left(X_{5}\right)$ had no effect on work productivity. The attitude $\left(X_{4}\right)$ had an effect on work productivity. The results of simultaneous hypothesis testing explained that knowledge $\left(X_{1}\right)$, skills $\left(X_{2}\right)$, abilities $\left(X_{3}\right)$, attitudes $\left(X_{4}\right)$ and behavior $\left(X_{5}\right)$ haved an effect on work productivity. The coefficient of determination of 0.636 means that knowledge, skills, abilities, attitudes and behavior are able to explain work productivity by $63.6 \%$. The remaining $36.4 \%$ is explained by other variables not included in this research model.
\end{abstract}

Keywords: Work Productivity, Knowledge, Skills, Abilities, Attitudes, Behaviors

\section{PENDAHULUAN}

Latar Belakang. Suatu perusahaan atau organisasi tidak dapat mencapai tujuannya secara efisien dan efektif apabila produktivitas kerja karyawan rendah. Oleh sebab itu produktivitas menjadi hal penting yang selalu ingin ditingkatkan karena dapat menggam-barkan tingkat efisiensi kerja karyawan. Untuk dapat mencapai target produk-tivitas, sumber daya manusia memegang peran penting, karena kegiatan perusahaan tidak mungkin dapat dilakukan dengan baik tanpa didukung oleh sumber daya manusia. Untuk mencapai hal tersebut, diperlukan suatu rangsangan untuk meningkatkan produktivitas kerja, agar tercapai tujuan perusahaan. Produktvitas kerja merupakan suatu kondisi dimana karyawan suatu perusahaan dapat bekerja secara maksimal sehingga hasil produksi yang dicapai dapat sesuai dengan apa yang direncanakan.

Peningkatan produktivitas merupakan salah satu faktor utama bagi perkembangan suatu perusahaan. Produktivitas menyangkut masalah hasil akhir, yakni seberapa besar hasil akhir yang diperoleh dalam proses produksi yang dalam hal ini tidak terlepas dari efisiensi dan efektivitas (Ambar dan Rosidah,2009). 
Tabel 1

Target, realisasi pendapatan, penjualan jasa dan ketercapaian di PT. Multi Terminal Indonesia

\begin{tabular}{cccc}
\hline Tahun & Pendapatan & Target Penjualan Jasa & $\begin{array}{c}\text { Ketercapaian } \\
(\%)\end{array}$ \\
\hline 2017 & 13.331 .924 .359 & 15.000 .000 .000 & 93 \\
\hline 2018 & 17.000 .000 .000 & 17.000 .000 .000 & 100 \\
\hline 2019 & 18.668 .474 .968 & 20.000 .000 .000 & 93 \\
\hline 2020 & 20.000 .000 .000 & 20.000 .000 .000 & 100 \\
\hline
\end{tabular}

Sumber : PT. Multi Terminal Indonesia tahun 2017 s/d 2020

PT. Multi Terminal Indonesia salah satu perusahaan yang memiliki komitmen untuk meningkatkan jasa layanan terbaik ekspor maupun impor kepada pelanggan, dan berkomitmen untuk menjadi perusahaan yang memberikan layanan terbaik di Semarang dengan harga yang relatif memuaskan. Untuk mencapai tujuan tersebut, dituntut produktivitas kerja karyawan dalam melaksanakan tugas dan tanggung jawab.

Tabel 1 menunjukkan target, realisasi, pendapatan, dan penjualan selama 4 tahun terkahir. Untuk melihat perkembangan produktivitas perusahaan dapat dilihat pada hasil laba rugi dari penjualan jasa yang diterima oleh PT. Multi Terminal Indonesia.

Dari data tabel 1 diatas terlihat bahwa penjualan kurang sesuai dengan target penjualan dari perusahaan, hal ini dibuktikan dengan data pada tabel yang menunjukkan adanya target penjualan yang fluktuatif sehingga belum mencapai seperti yang diharapkan perusahaan. Dengan hasil yang fluktuatif tersebut dapat diartikan bahwa karyawan kurang tanggap dalam melaksanakan tugasnya. Salah satu alasan tidak tercapainya target ini dikarenakan permintaan dari pelanggan untuk pengiriman dalam waktu yang cepat dengan armada trucking namun perusahaan masih kesulitan dalam hal tersebut. Oleh karena itu perusahaan sangat memerlukan operasional yang bersedia berada di lapangan serta support admin.
Untuk mencapai tujuan perusahaan diperlukan profesionalitas dengan tingkat produktivitas kerja yang tinggi sehingga mampu menyediakan kebutuhan pelanggan. Apabila tersedianya tenaga kerja atau karyawan yang mempunyai produktivitas tinggi maka diharapkan adanya kualitas yang maksimal akan kebutuhan tenaga profesional yang mampu ikut bekerjasama dalam memberikan pelayanan dan kelengkapan lainnya yang berhubungan dengan kemajuan dari bisnis atau usaha yang sedang dijalankan.

Atas dasar uraian diatas, maka tujuan dari penelitian ini yaitu menganalisis pengaruh pengetahuan, ketrampilan, kemampuan, sikap, dan perilaku baik secara parsial maupun simultan terhadap produktivitas karyawan PT. Multi Terminal Indonesia.

\section{TINJAUAN TEORITIS}

Produktivitas. Sunyoto (2013) dalam bukunya yang berjudul Manajemen Sumber Daya Manusia mendefinisikan produktivitas adalah ukuran yang menunjukkan pertimbangan antara input dan output yang dikeluarkan perusahaan serta peran tenaga kerja yang dimiliki persatuan waktu, atau dengan kata lain mengukur efisiensi memerlukan identi-fikasi dari hasil kinerja. Aspek-aspek produktivitas terdiri dari perbaikan terus menerus, tugas pekerjaan yang menantang, kondisi fisik tempat bekerja, motivasi kerja, efisiensi dan efektivitas kerja, kemampuan kerja, pengalaman dan pengetahuan. Menurut 
Sinungan dalam Busro (2018), produktivitas kerja merupakan kemampuan seseorang atau sekelompok orang untuk menghasilkan barang dan jasa dalam waktu tertentu yang telah ditentukan atau sesuai dengan rencana. Jadi produktivitas merupakan sikap mental karyawan yang mencer-minkan kemampuan karyawan dalam melakukan pekerjaan dan hasil yang diperoleh berdasarkan sumber daya yang digunakan.

Pengetahuan $\left(\mathbf{X}_{1}\right)$. Pengetahuan sangat penting bagi sebuah perusahaan. Sehingga perusahaan tersebut mampu berkembang semakin pesat. Knowledge management berfungsi sebagai pendekatan yang tetap terencana secara sistematis agar dapat menjamin penerapan pengetahuan organisasi yang lebih baik. Dengan begitu organisasi akan mampu berjalan dengan lebih terarah, semakin efektif dan efisien. Menurut Sunyoto (2013) pengetahuan (knowledge) sesungguhnya yang mendasari pencapaian produktivitas kerja. Pengetahuan merupakan akumulasi hasil proses pendidikan baik yang di peroleh secara formal maupun non formal yang memberikan kontribusi pada seseorang di dalam pemecahan masalah, daya cipta, termasuk dalam melakukan atau menyelesaikan pekerjaan. Ada beberapa faktor yang dapat mempengaruhi pengetahuan seseorang. Fitriani (2015) berpendapat bahwa faktor-faktor tersebut adalah sebagai berikut :

1. Pendidikan. Pendidikan adalah suatu usaha untuk mengem-bangkan keperibadian dan kemampuan di dalam dan di luar sekolah yang berlangsung seumur hidup. Pendidikan mempengaruhi proses belajar, semakin tinggi pendidikan seseorang maka sema-kin mudah orang tersebut untuk mene-rima informasi. Pendidikan tinggi sese-orang akan mendapatkan informasi baik dari orang lain maupun media massa. Semakin banyak informasi yang masuk, semakin banyak pula pengetahuan yang didapat tentang kesehatan. Peningkatan pengetahuan tidak mutlak diperoleh di pendidikan formal, akan tetapi dapat diperoleh pada pendidikan non formal. Pengetahuan seseorang tentang suatu objek mengandung dua aspek yaitu aspek positif dan aspek negatif. Kedua aspek ini akan menentukan sikap seseorang terhadap objek tertentu. Semakin banyak aspek positif dari objek yang diketahui akan menumbuhkan sikap positif terhadap objek tersebut.

2. Media Massa / informasi. Informasi yang diperoleh baik dari pendidikan formal maupun non formal dapat memberikan pengetahuan jangka pendek (impact), sehingga menghasilkan perubahan dan peningkatan pengetahuan. Kemajuan tekno-logi menyediakan bermacam-macam media massa yang dapat mempengaruhi penge-tahuan masyarakat tentang informasi baru. Sarana komunikasi seperti televisi, radio, surat kabar, majalah, penyuluhan, dan lain-lain pempunyai pengaruh besar terhadap pembentukan opini dan kepercayaan orang.

3. Sosial Budaya dan Ekonomi. Kebiasaan dan tradisi yang dilakukan seseorang tanpa melalui penalaran apakah yang dilakukan itu baik atau tidak. Status ekonomi seseorang juga akan menentukan ketersediaan fasilitas yang diperlukan untuk kegiatan tertentu, sehingga status sosial ekonomi akan mempengaruhi pengetahuan seseorang.

4. Lingkungan. Lingkungan adalah segala sesuatu yang ada di sekitar individu baik lingkungan fisik, biologis, maupun sosial. Lingkungan berpengaruh terhadap proses masuknya pengetahuan ke dalam individu yang berada pada lingkungan tersebut. Hal tersebut terjadi karena adanya interaksi timbal balik yang akan direspon sebagai pengetahuan

5. Pengalaman. Pengetahuan dapat diperoleh dari pengalaman pribadi ataupun pengalaman orang lain. Pengalaman ini merupakan suatu cara untuk memperoleh kebenaran suatu pengetahuan. 
6. Usia. Usia mempengaruhi daya tangkap dan pola pikir seseorang. Bertambahnya usia akan semakin berkem-bang pola pikir dan daya tangkap seseorang sehingga pengetahuan yang diperoleh akan semakin banyak.

Keterampilan $\left(\mathbf{X}_{\mathbf{2}}\right)$. Menurut Ambar dan Rosidah (2009) keterampilan (skills) adalah kemampuan dan penguasaan teknis operasional mengenai bidang tertentu, yang bersifat kekaryaan. Keterampilan diperoleh melalui proses belajar dan berlatih. Keterampilan berkaitan dengan kemampuan seseorang untuk melakukan atau menyelesaikan pegawai-pegawai yang bersifat teknis, seperti keterampilan komputer, keterampilan bengkel dan lain lain. Faktor faktor yang mempengaruhi keterampilan

1. Motivasi. Motivasi merupakan sesuatu yang membangkitkan keinginan dalam diri seseorang untuk melakukan berbagai tindakan. Motivasi inilah yang mendorong seseorang bisa melakukan tindakan sesuai dengan prosedur yang sudah diajarkan.

2. Pengalaman. Pengalaman merupakan suatu hal yang akan memperkuat kemampuan seseorang dalam melakukan sebuah tindakan (keterampilan). Pengalaman membangun seseorang untuk bisa melakukan tindakan-tindakan selanjutnya menjadi lebih baik yang dikarenakan sudah melakukan tindakantindakan di masa lampaunya.

3. Keahlian. Keahlian yang dimiliki seseorang akan membuat terampil dalam melakukan keterampilan tertentu. Keahlian akan membuat seseorang mampu melakukan sesuatu sesuai dengan yang sudah diajarkan.

Kemampuan $\left(\mathbf{X}_{3}\right)$. Menurut Sunyoto (2013) kemampuan terbentuk dari sejumlah kompetensi yang dimiliki oleh seorang karyawan. Pentingnya kemampuan karen hal yang menyebabkan, menyalurkan, dan mendukung kinerja karyawan, supaya mau bekerja giat dan antusias mencapai hasil yang optimal. Kemampuan semakin penting karena manajer memberikan pekerjaan pada bawahannya untuk dikerjakan dengan baik dan terintegrasi kepada tujuan yang diinginkan. Perusahaan bukan saja mengharapkan karyawan mampu, cakap, dan terampil,tetapi yang terpenting mereka dapat bekerja dengan hasil yang maksimal. Menurut Michael Zwell dalam Wibowo (2007) mengungkapkan bahwa terdapat, beberapa faktor yang dapat mempengaruhi kemampuan seseorang karyawan, yaitu sebagai berikut :
1. Keyakinan dan Nilai - nilai
2. Keterampilan
3. Pengalaman
4. Karakteristik kepribadian
5. Motivasi
6. Isu emosional

Sikap (X). Menurut Sunyoto (2013) sikap merupakan suatu kebiasaan yang terpolakan. Menurut Ambar dan Rosidah (2009) attitude (sikap) merupakan suatu kebiasaan yang terpolakan. Jika kebisaan terpolakan tersebut memiliki implikasi positif dalam hubungannya dengan perilaku kerja seseorang maka akan menguntungkan. Arti yang dimaksudkan diatas, apabila kebiasaan-kebiasaan pega-wai adalah baik, maka hal tersebut dapat menjamin perilaku kerja yang baik pula. Blum and Nylon (2008) menyatakan beberapa faktor yang mempengaruhi sikap kerja antara lain:

1. Kondisi kerja, meliputi lingkungan fisik maupun sosial berpengaruh terhadap kenyamanan dalam bekerja.

2. Pengawasan atasan, pengawasan dan perhatian yang baik dari atasan dapat mempengaruhi sikap dan semangat kerja.

3. Kerja sama dari teman sekerja, adanya kerja sama dari teman sekerja juga berpengaruh dengan kualitas dan prestasi dalam menyelesaikan pekerjaan.

4. Kesempatan untuk maju, jaminan terhadap karir dan hari tua dapat dijadikan salah satu motivasi dalam sikap kerja.

5. Keamanan. Rasa aman dan ling-kungan yang terjaga akan menjamin dan menambah ketenangan dalam bekerja. 
6. Fasilitas kerja. Fasilitas kerja yang memadai berpengaruh terhadap terciptanya sikap kerja yang positif.

Imbalan. Rasa senang terhadap imbalan yang diberikan baik berupa gaji pokok maupun tunjangan mempe-ngaruhi sikap dalam menyelesaikan pekerjaannya.

Perilaku $\quad\left(\mathbf{X}_{\mathbf{5}}\right)$. Perilaku kerja merupakan bagian yang berperan sangat penting dalam kehidupan bekerja. Peri-laku kerja merupakan tindakan dan sikap yang ditunjukan oleh orang-orang yang bekerja. Menurut Gomes (2003) perilaku (behaviors) adalah suatu komponen perilaku dari suatu sikap atau maksud cara berperilaku terhadap seseorang Manusia diciptakan sebagai makhluk pengemban nilai-nilai moral, adanya akal dan budi pada manusia menyebabkan adanya perbedaan cara dan pola hidup yang berdimensi ganda, yakni kehidupan yang bersifat material dan kehidupan yang bersifat spiritual. Akal dan budi sangat berperan dalam usaha menciptakan pola hidup atau perilaku manusia itu sendiri. Selain akal dan budi tersebut di atas, ada beberapa faktor yang mempengaruhi perilaku manusia. Menurut Kotler (2001) faktor-faktor yang mempengaruhi perilaku konsumen adalah kebudayaan, faktor sosial, pribadi, psikologis.

1. Budaya. Kebudayaan merupakan penentu keinginan dan perilaku yang paling mendasar untuk mendapatkan nilai, persepsi, preferensi dan perilaku dari lembaga-lembaga penting lainnya. Faktor kebudayaan memberikan pengaruh paling luas dan dalam pada tingkah laku konsumen. Faktor kebudayaan, terdiri dari : budaya, sub budaya, kelas sosial.

2. Kelas sosial. Merupakan pembagian masyarakat yang relatif homogen dan permanen yang tersusun secara hierarkis dan yang anggotanya menganut nilainilai, minat, dan perilaku yang serupa. faktor sosial, terdiri dari : kelompok, keluarga, peran dan status.

3. Faktor pribadi. Faktor pribadi didefinisikan sebagai karakteristik psikologis seseorang dengan orang lain yang menyebabkan tanggapan yang relatif.

4. Psikologis. Sebagai bagian dari pengaruh lingkungan di mana ia tinggal dan hidup pada waktu sekarang tanpa mengabaikan pengaruh dimasa lampau atau antisipasinya pada waktu yang akan datang. Faktor psikologis, terdiri dari motivasi, persepsi, pengetahuan, keyakinan dan sikap.

Penelitian Terdahulu. Berikut ini beberapa penelitian terdahulu yang pernah dilakukan terkait dengan kinerja, terangkum pada tabel 2 berikut :

\section{Hipotesis}

1. $\mathrm{H}_{1}=$ Diduga pengetahuan berpengaruh terhadap produktivitas kerja karyawan di PT. Multi Terminal Indonesia

2. $\mathrm{H}_{2}=$ Diduga keterampilan berpengaruh terhadap produktivitas kerja karyawan di PT. Multi Terminal Indonesia

3. $\mathrm{H}_{3}=$ Diduga kemampuan berpengaruh terhadap produktivitas kerja karyawan di PT. Multi Terminal Indonesia

4. $\mathrm{H}_{4}=$ Diduga sikap berpengaruh terhadap produktivitas kerja karyawan di PT. Multi Terminal Indonesia

5. $\mathrm{H}_{5}=$ Diduga perilaku berpengaruh terhadap produktivitas kerja karyawan di PT. Multi Terminal Indonesia

6. $\mathrm{H}_{6}=$ Diduga pengetahuan, keterampilan, kemampuan, sikap dan perilaku berpengaruh secara bersamaan terhadap produktivitas kerja karyawan di PT. Multi Terminal Indonesia. 
Tabel 2

Penelitian Terdahulu

\begin{tabular}{|c|c|c|c|c|}
\hline No & $\begin{array}{l}\text { Peneliti } \\
\text { dan } \\
\text { Tahun }\end{array}$ & Judul Penelitian & $\begin{array}{l}\text { Variabel } \\
\text { Penelitian }\end{array}$ & Hasil Penelitian \\
\hline 1 & $\begin{array}{l}\text { Supriyanto } \\
(2012)\end{array}$ & 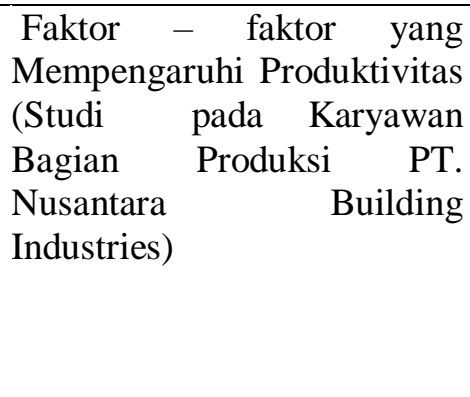 & $\begin{array}{l}\text { Dependen : } \\
\text { Produktivitas } \\
\text { Independen : } \\
\text { Knowledge, } \\
\text { Skills, Abillities, } \\
\text { Attitudes, } \\
\text { Behaviors }\end{array}$ & $\begin{array}{l}\text { Hasil dari penelitian } \\
\text { Menggambarkan bahwa } \\
\text { knowledge, skills, abillities, } \\
\text { attitude dan behaviors secara } \\
\text { parsial maupun simultan } \\
\text { berpengaruh signifikan dan } \\
\text { positif terhadap produktivitas } \\
\text { keryawan bagian produksi PT. } \\
\text { Nusantara Building Industries. }\end{array}$ \\
\hline ( & $\begin{array}{l}\text { Fendi } \\
\text { Atmoko } \\
(2016)\end{array}$ & $\begin{array}{l}\text { Pengaruh } \\
\text { Skills, Abilities, Attitude } \\
\text { dan Behaviors Terhadap } \\
\text { Produktivitas Kerja (Studi } \\
\text { Pada Karyawan Bagian } \\
\text { Produksi PT. Sango } \\
\text { Indonesia Semarang) }\end{array}$ & $\begin{array}{l}\text { Dependen : } \\
\text { Produktivitas } \\
\text { Independen : } \\
\text { Knowledge, } \\
\text { Skills, Abillities, } \\
\text { Attitudes, } \\
\text { Behaviors }\end{array}$ & $\begin{array}{l}\text { Hasil dari penelitian ini } \\
\text { menunjukkan bahwa ada } \\
\text { hubungan yang positif antara } \\
\text { knowledge, skills, abillities, } \\
\text { attitude terhadap produktivitas } \\
\text { kerja dan adanya hubungan } \\
\text { yang negatif behaviors } \\
\text { terhadap produktivitas. }\end{array}$ \\
\hline 3 & $\begin{array}{l}\text { Eko } \\
\text { Wahyono } \\
\text { (2015) }\end{array}$ & 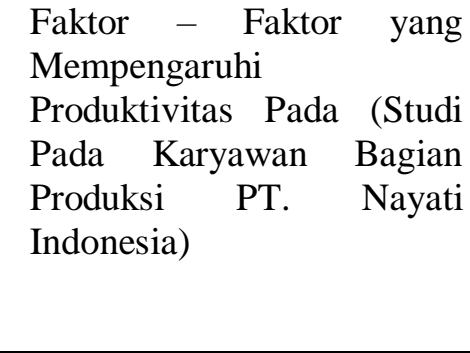 & $\begin{array}{l}\text { Dependen : } \\
\text { Produktivitas } \\
\text { Independen : } \\
\text { Pengetahuan, } \\
\text { Keterampilan, } \\
\text { Kemampuan, } \\
\text { Sikap, Perilaku }\end{array}$ & $\begin{array}{l}\text { Hasil penelitian menjelaskan } \\
\text { bahwa ada hubungan positif } \\
\text { signifikan antara pengetahuan, } \\
\text { sikap dan perilaku terhadap } \\
\text { produktivitas kerja dan adanya } \\
\text { hubungan negatif antara } \\
\text { keterampilan, kemampuan } \\
\text { terhadap produktivitas kerja. }\end{array}$ \\
\hline 4 & $\begin{array}{l}\text { Iswandi } \\
\text { Idris } \\
\text { (2016) }\end{array}$ & $\begin{array}{l}\text { Produktivitas Kerja } \\
\text { Karyawan Perbankan di } \\
\text { Kota Medan }\end{array}$ & $\begin{array}{l}\text { Dependen : } \\
\text { Produktivitas } \\
\text { Independen : } \\
\text { Motivasi } \\
\text { Pengetahuan } \\
\text { Keterampilan } \\
\text { Penghasilan } \\
\end{array}$ & $\begin{array}{l}\text { Hasil penelitian menjelaskan } \\
\text { bahwa tidak ada pengaruh } \\
\text { secara signifikan antara } \\
\text { motivasi, pengetahuan, } \\
\text { keterampilan dan penghasilan } \\
\text { terhadap produktivitas kerja. }\end{array}$ \\
\hline
\end{tabular}

\section{Gambar 1 \\ Kerangka Teoritis Penelitian}

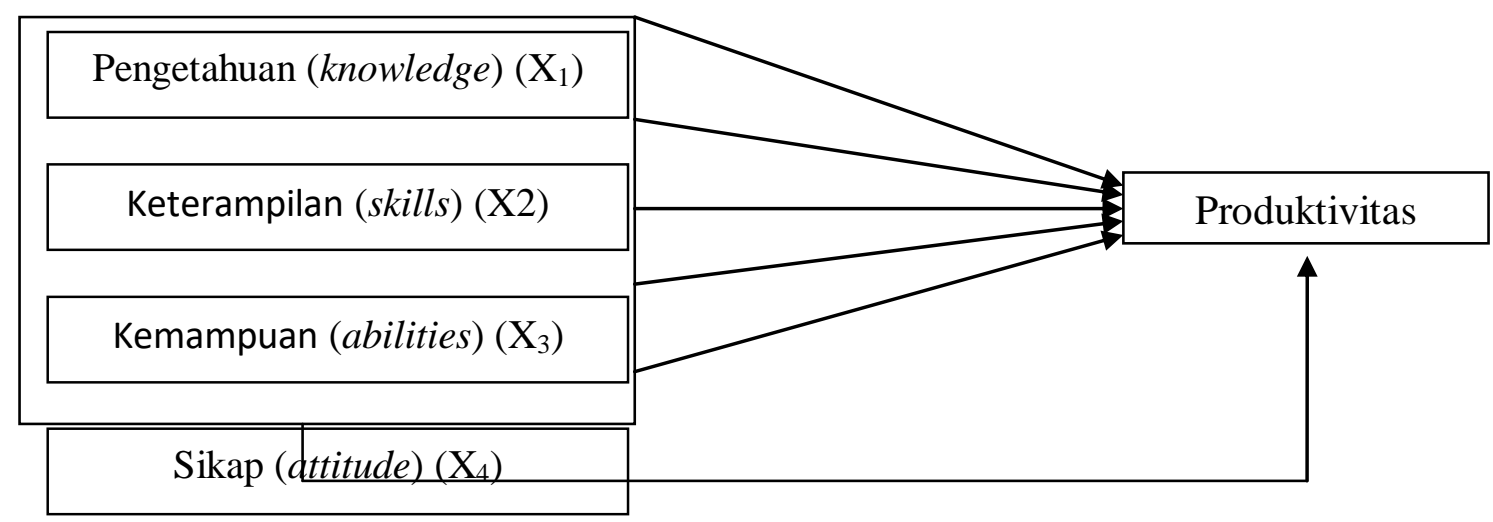

Perilaku (behaviors) $\left(\mathrm{X}_{5}\right)$ 


\section{METODE PENELITIAN}

Jenis Penelitian. Jenis penelitian dalam penelitian ini adalah penelitian asosiatif, yaitu penelitian yang bertujuan untuk mengetahui hubungan dua variabel atau lebih, dalam hal ini untuk mengetahui pengaruh pengetahuan, keterampilan, kemampuan, sikap, dan perilaku terhadap produktivitas karyawan di PT. Multi Terminal Indonesia.

Lokasi Penelitian. Penelitian ini dilakukan pada PT. Multi Terminal Indonesia J1. Pamularsih Raya No. 5-H, Bongsari, Kec. Semarang Barat, Semarang Jawa Tengah

Populasi. Populasi dalam penelitian ini adalah seluruh karyawan PT. Multi Terminal Indonesia, yang berjumlah 30 orang.

Banyaknya Sampel. Sampel dalam penelitian ini diambil dari seluruh jumlah populasi atau disebut dengan sampling jenuh sehingga jumlah sampel dalam penelitian ini sebanyak 30 karyawan.

Jenis Data. Jenis data yang dipakai dalam penelitian ini berupa data subyek yaitu kuesioner yang dibagikan kepada karyawan PT. Multi Terminal Indonesia.

\section{Sumber Data}

\section{Data Primer}

Data primer dalam penelitian ini adalah kuesioner yang dibagikan pada seluruh karyawan PT. Multi Terminal Indonesia.

2. Data sekunder

Data sekunder yang dipakai terkait jumlah karyawan bagian produksi PT. Multi Terminal Indoneisa.

Teknik Pengumpulan Data. Teknik pengumpulan data dengan membagikan kuesioner kepada seluruh karyawan PT. Multi Terminal Indonesia.

Teknik Analisis Data. Alat analisis yang digunakan dalam penelitian ini yaitu regresi linear berganda. Adapun bentuk umum persamaan regresi linear berganda dengan lima variabel bebas adalah sebagai berikut :

$$
\begin{aligned}
& \mathrm{Y}=\mathrm{b}+\mathrm{b}_{1} \mathrm{X}_{1}+\mathrm{b}_{2} \mathrm{X}_{2}+\mathrm{b}_{3} \mathrm{X}_{3}+\mathrm{b}_{4} \mathrm{X}_{4}+\mathrm{b}_{5} \mathrm{X}_{5} \\
& \mathrm{Y}=\text { Produktivitas karyawan } \\
& \mathrm{b}_{1}, \mathrm{~b}_{2}, \mathrm{~b}_{3}, \mathrm{~b}_{4}, \mathrm{~b}_{5} \text { adalah koefisien parsial } \\
& \text { untuk masing-masing variabel } \\
& \mathrm{X}_{1}, \mathrm{X}_{2}, \mathrm{X}_{3}, \mathrm{X}_{4}, \mathrm{X}_{5} \\
& \mathrm{X}_{1}=\text { pengetahuan } \\
& \mathrm{X}_{2}=\text { keterampilan } \\
& \mathrm{X}_{3}=\text { kemampuan } \\
& \mathrm{X}_{4}=\text { sikap } \\
& \mathrm{X}_{5}=\text { perilaku }
\end{aligned}
$$

\section{HASIL DAN PEMBAHASAN}

Uji Validitas dan Reliabilitas. Dari hasil uji validitas, semua item pertanyaan memiliki nilai korelasi positif dan lebih besar dari 0,6. Hal ini berarti bahwa semua instrumen dalam penelitian ini adalah valid. Begitu pula, hasil uji reliabilitas menunjukkan semua variabel memiliki nilai koefisien Chronbach Alpha lebih besar dari 0,6, yang artinya bahwa seluruh instrumen yang digunakan dalam penelitian ini adalah reliabel.

Uji Asumsi Klasik. Sebelum dilakukan uji regresi linier berganda maka dilakukan uji asumsi klasik, dari hasil uji multikolerianitas menunjukkan bahwa tidak ada nilai VIF yang lebih dari 10 sehingga dapat dikatakan bahwa tidak ada korelasi antara variabel bebas. Selanjutnya nilai signifikansi tiap variabel terhadap absolute residual lebih dari 0,05, artinya persamaan regresi mengalami homokedastisitas (tidak mengandung Heterokedastisitas) dan untuk uji normalitas data penelitian ini berdistribusi normal, dikarenakan nilai $\alpha$ lebih besar dari 0,05 .

Uji Regresi Linier Berganda. Analisis regresi berganda dilakukan meliputi variabel bebas pengetahuan $\left(\mathrm{X}_{1}\right)$, ketrampilan $\left(\mathrm{X}_{2}\right)$, kemampuan $\left(\mathrm{X}_{3}\right)$, sikap $\left(\mathrm{X}_{4}\right)$, perilaku $\left(\mathrm{X}_{5}\right)$ terhadap variabel terikat produktivitas karyawan (Y). Berikut adalah hasilnya :

Berdasarkan tabel 3, maka diperoleh persamaan regresi linier berganda sebagai berikut : 
Tabel 3

Regresi Linier Berganda

Coefficients $^{\mathbf{a}}$

\begin{tabular}{rlccccc}
\hline & Model & \multicolumn{2}{c}{$\begin{array}{c}\text { Unstandardized } \\
\text { Coefficients }\end{array}$} & $\begin{array}{c}\text { Standardized } \\
\text { Coefficients }\end{array}$ & $\mathrm{t}$ & \multirow{2}{*}{ Sig. } \\
\cline { 3 - 5 } $\mathrm{e}$ & & $\mathrm{B}$ & $\begin{array}{c}\text { Std. } \\
\text { Error }\end{array}$ & Beta & & \\
$\mathrm{nnyyynn} \mathrm{p}$ & & & & & \\
\hline 1e & (Constant) & 6,188 & 3,107 & & 1,992 & 0,058 \\
$\mathrm{n}$ & Pengetahuan & 0,144 & 0,628 & 0,039 & 0,23 & 0,82 \\
$\mathrm{~d}$ & Keterampilan & 0,854 & 0,562 & 0,368 & 1,519 & 0,142 \\
$\mathrm{e}$ & Kemampuan & $-0,606$ & 0,724 & $-0,144$ & $-0,836$ & 0,411 \\
$\mathrm{n}$ & Sikap & 0,522 & 0,21 & 0,462 & 2,486 & 0,02 \\
$\mathrm{t}$ & Perilaku & 0,164 & 0,167 & 0,156 & 0,981 & 0,336 \\
\hline
\end{tabular}

Variable: Produktivitas

Sumber : Output SPSS 2021

Tabel 4

Uji F

ANOVA $^{\mathrm{a}}$

\begin{tabular}{ccccccc}
\hline \multirow{2}{*}{ Model } & $\begin{array}{c}\text { Sum of } \\
\text { Squares }\end{array}$ & Df & $\begin{array}{c}\text { Mean } \\
\text { Square }\end{array}$ & F & Sig. \\
\hline 1 & Regression & 735,356 & 5 & 147,071 & 11,152 &, $000^{\mathrm{b}}$ \\
& Residual & 316,51 & 24 & 13,188 & & \\
& Total & 1051,867 & 29 & & & \\
\hline \multicolumn{6}{c}{ a. Dependent Variable: PRODUKTIVITAS } \\
\hline
\end{tabular}

Koefisien Determinasi $\left(\mathbf{R}^{2}\right)$

Tabel 5

Uji Koefisien Determinasi $\left(\mathbf{R}^{2}\right)$

\begin{tabular}{ccccc}
\hline Model & $\mathrm{R}$ & R Square & $\begin{array}{c}\text { Adjust } \\
\text { ed } \mathrm{R} \\
\text { Square }\end{array}$ & $\begin{array}{c}\text { Std. Error of } \\
\text { the Estimate }\end{array}$ \\
\hline 1 &, $836^{\mathrm{a}}$ & 0,699 & 0,636 & 3,632 \\
\hline
\end{tabular}

a. Predictors: (Constant), Perilaku, Kemampuan, Sikap, Pengetahuan, Keterampilan

b. b. Dependent Variable: Produktivitas

Sumber : Output SPSS 2021

$\mathrm{Y}=\mathrm{b}+\mathrm{b}_{1} \mathrm{X}_{1}+\mathrm{b}_{2} \mathrm{X}_{2}+\mathrm{b}_{3} \mathrm{X}_{3}+\mathrm{b}_{4} \mathrm{X}_{4}+\mathrm{b}_{5} \mathrm{X}_{5}$

$\mathrm{Y}=6,188+0,144 \mathrm{X}_{1}+0,854 \mathrm{X}_{2}-0,606 \mathrm{X}_{3}$ $+0,522 X_{4}+0,164 X_{5}$

Dari perhitungan beta coefficient menunjukkan bahwa dari kelima variabel tersebut yang berpengaruh terhadap variabel dependen produktivitas karyawan (Y) yaitu faktor sikap. Dari hasil penelitian ini nilai Adjusted $\mathrm{R}$ square $\left(\mathrm{R}^{2}\right)$ yaitu sebesar 0,636 artinya variabel faktor budaya, faktor sosial, faktor pribadi, faktor psikologi mampu menjelaskan perilaku konsumen (Y) dalam pembelian sabun cair sebesar $63,6 \%$, sedangkan sisanya sebesar $36,4 \%$ dipengaruhi oleh variabel lain yang tidak diteliti dalam penelitian ini.

Pengaruh Pengetahuan

$\left(\mathbf{X}_{1}\right)$ terhadap Produktivitas Kerja (Y). Atas dasar pengujian hipotesis secara parsial, diperoleh nilai $\mathrm{t}$ hitung $0,230<\mathrm{t}$ tabel $=$ $2,064(0,230<2,064)$ dengan tingkat signifikansi 0,820. Dengan demikian Ho 
diterima dan Ha ditolak, yang artinya tidak ada pengaruh pengetahuan $\left(\mathrm{X}_{1}\right)$ secara parsial terhadap produktivitas (Y).

Teori Gomez (2003) menyatakan bahwa salah satu faktor yang mempengaruhi peroduktivitas adalah knowledge. Pengetahuan merupakan akumulasi hasil proses pendidikan baik yang diperoleh secara formal maupun non formal yang memberikan kontribusi pada seseorang didalam pemecahan masalah, daya cipta, termasuk melakukan atau menyelesaikan pekerjaan. Namun penelitian ini menghasilkan temuan, bahwa perusahaan tidak membutuhkan pengetahuan yang tinggi untuk melakukan suatu pekerjaan, dikarenakan pengetahuan yang dimiliki oleh karyawan sudah sesuai dengan penempatan kerja di divisi masing-masing.

Hasil penelitian ini sesuai dengan penelitian yang dilakukan Iswandi Idris (2016), yang menyatakan bahwa secara parsial pengetahuan tidak berpengaruh signifikan terhadap produktivitas.

Pengaruh Keterampilan (X2) terhadap Produktivitas Kerja (Y). Hasil pengujian hipotesis secara parsial menunjukkan nilai $\mathrm{t}$ hitung $1,519<\mathrm{t}$ tabel $=2,064(1,519<$ $2,064)$ dengan tingkat signifikansi 0,142 , yang berarti Ho ditolak dan Ha diterima, yang artinya tidak ada pengaruh yang positif signifikan variabel keterampilan (X2) secara parsial terhadap produktivitas (Y). Hal ini mengindikasikan bahwa semakin tinggi keterampilan belum tentu semakin tinggi tingkat produktivitas kerja. Sebaliknya, semakin rendah keterampilan karyawan belum tentu juga semakin rendah tingkat produktivitas kerja.

Hasil penelitian ini sesuai dengan teori Gomez (2003), yang menyebutkan bahwa skill (keterampilan) adalah suatu kecakapan yang berhubungan dengan tugas yang dimiliki dan dipergunakan oleh seseorang pada waktu yang tepat. Seorang karyawan sangat dibutuhkan dalam perusahaan dalam melaksanakan pekerjaannya. Namun, hasil temuan penelitian ini menyebutkan bahwa karyawan pada PT. Multi Terminal
Indonesia karyawan sudah dimudahkan dalam melakukan pekerjaannya, dengan alat teknologi yang canggih sehingga tidak memerlukan keterampilan yang tinggi dalam menyelesaikan pekerjaan. Karyawan hanya dituntut dapat mengoperasikan alat yang sudah disediakan perusahaan. Dengan demikian keterampilan yang bagus dan baik tidak terlalu di utamakan dalam perusahaan ini. Namun hanya perlu pemahaman yang baik dalam pengoperasian alat-alat yang tersedia.

Hasil penelitian ini sesuai dengan hasil penelitian Eko Wahyono (2015) yang menyatakan bahwa keterampilan tidak berpengaruh positif signifikan terhadap produktivitas kerja. Artinya dengan bertambahnya keterampilan karyawan, maka tidak akan mengakibatkan naiknya produktivitas.

Pengaruh Kemampuan (X3) terhadap Produktivitas Kerja (Y). Nilai t-hitung kemampuan (X3) dalam penelitian ini sebesar $-0,836<\mathrm{t}$ tabel $=2,064$, dengan tingkat signifikansi 0,411 . Hal ini berarti bahwa Ho diterima dan Ha ditolak, yang artinya tidak ada pengaruh yang positif signifikan variabel kemampuan (X3) secara parsial terhadap produktivitas (Y). Hal ini mengindikasikan bahwa semakin tinggi kemampuan belum tentu semakin tinggi tingkat produktivitas kerja. Sebaliknya, semakin rendah kemampuan karyawan belum tentu juga semakin rendah tingkat produktivitas kerja. Dengan demikian hipotesis yang menyatakan bahwa kemampuan (X3) berpengaruh terhadap produktivitas ditolak.

Berdasarkan teori Gomes (2003) bahwa salah satu faktor yang mempengaruhi produktivitas adalah abilities karyawan. Dengan memiliki pengetahuan dan keterampilan yang tinggi, diharapkan memiliki kemampuan yang tinggi pula. Namun hasil temuan dalam penelitian menyebutkan bahwa, karyawan PT. Multi Terminal Indonesia tidak membutuhkan kemampuan yang tinggi, karena karyawan PT. Multi Terminal Indonesia sudah 
ditetapkan pekerjaannya dari awal oleh perusahaan. Dengan demikian kemampuan yang tinggi tidak dibutuhkan dalam perusahaan ini.

Hasil penelitian ini sesuai dengan hasil penelitian Eko Wahyono (2015) yang menyatakan bahwa pengetahuan tidak berpengaruh positif signifikan terhadap produktivitas kerja. Artinya dengan bertambahnya pengetahuan karyawan, maka tidak akan mengakibatkan naiknya produktivitas.

Pengaruh sikap (X4) terhadap produktivitas kerja (Y). Nilai t-hitung sikap (X4) pada pengujian hipotesis secara parsial sebesar 2,486 > t tabel $=2,064(2,486>$ 2,064) dengan tingkat signifikansi 0,020 yang berarti Ho ditolak dan Ha diterima, artinya ada pengaruh sikap (X4) secara parsial terhadap produktivitas (Y). Hal ini menyatakan bahwa semakin tinggi sikap karyawan, maka semakin tinggi pula tingkat produktivitas namun sebaliknya semakin rendah sikap karyawan, maka semakin rendah pula tingkat produktivitas. Dengan demikian hipotesis yang menyatakan bahwa sikap (X4) berpengaruh terhadap produktivitas kerja, diterima.

Sesuai dengan teori Sunyoto (2013) bahwa salah satu faktor yang mempengaruhi produktivitas kerja adalah sikap. Salah satu yang menjadi kebutuhan karyawan dalam bekerja adalah kebutuhan akan sikap dan perhatian dari atasan, serta lingkungan yang mendukung karyawan dalam bekerja. Dengan demikian perilaku manusia juga akan di tentukan oleh kebiasaan-kebiasaan yang tertanam dalam diri karyawan sehingga dapat mendukung kerja yang efektif atau sebaliknya dengan kondisi karyawan tersebut, maka produktivitas dapat dipastikan terwujud.

Hasil penelitian ini sesuai dengan penelitian terdahulu yang dilakukan oleh Supriyanto (2012) yang menyatakan bahwa pengetahuan berpengaruh terhadap produktivitas kerja.

Pengaruh perilaku (X5) terhadap produktivitas kerja (Y). Hasil pengujian hipotesis secara parsial untuk perilaku (X5) diperoleh nilai $\mathrm{t}$ hitung $0,981<\mathrm{t}$ tabel $=$ $0,981(0,336<0,981)$ dengan tingkat signifikansi 0,820 yang berarti Ho diterima dan Ha ditolak, artinya tidak ada pengaruh yang positif signifikan variabel perilaku (X5) secara parsial terhadap produktivitas (Y). Hal ini mengindikasikan bahwa semakin tinggi perilaku belum tentu semakin tinggi tingkat produktivitas kerja. Sebaliknya, semakin rendah perilaku karyawan belum tentu juga semakin rendah tingkat produktivitas kerja. Dengan demikian hipotesis yang menyatakan bahwa perilaku (X5) berpengaruh terhadap produktivitas ditolak. Hasil penelitian ini sesuai teori Rosidah (2009) yang menyatakan bahwa perilaku ditentukan oleh kebiasaan-kebiasaan yang telah tertanam dari diri seorang karyawan sehingga dapat mendukung kerja yang seefektif mungkin atau sebaliknya. Di dalam perilaku karyawan pasti terdapat perilaku yang berbeda-beda antara karyawan, ada perilaku yang baik seperti karyawan yang selalu datang tepat waktu, dan melakukan pekerjaan dengan baik dan seefisien mungkin. Sedangkan perilaku yang buruk bagi karyawan seperti sering datang terlambat, tidak menyelesaikan pekerjaan dengan baik dan lalai. Karyawan PT. Multi Terminal Indonesia sudah menerapkan perilaku yang baik, dikarenakan pekerjaan dibagi menjadi dua shift karyawan PT. Multi Terminal Indonesia selalu datang menurut waktu yang di tetapkan oleh perusahaan, begitu pula dengan pekerjaan masing-masing sudah sesuai dengan porsi perbagian.

Hasil penelitian ini sesuai dengan hasil penelitian Fendi Atmoko (2016) yang menyatakan bahwa perilaku (behaviors) tidak berpengaruh positif signifikan terhadap produktivitas kerja. Artinya dengan bertambahnya perilaku, maka tidak akan mengakibatkan naiknya produktivitas.

Pengaruh pengetahuan (X1), keterampilan (X2), kemampuan (X3), sikap (X4), dan perilaku (X5) secara bersama- 
sama terhadap produktivitas kerja (Y). Hasil pengujian hipotesis secara simultan menunjukkan pada taraf $\alpha=5 \%$ atau 0,05 diperoleh $\mathrm{F}$ hitung $>\mathrm{F}$ tabel $(11,152>3,35)$ dan signifikan sebesar $0,000<0,05$, maka pengetahuan (X1), keterampilan (X2), kemampuan (X3), sikap (X4), dan perilaku (X5) secara bersama-sama berpengaruh terhadap produktivitas kerja (Y). Hal ini menyatakan bahwa semakin tinggi pengetahuan, keterampilan, kemampuan, sikap, dan perilaku maka semakin tinggi pula produktivitas kerja, begitu pula sebaliknya semakin rendah pengetahuan, keterampilan, kemampuan, sikap, dan perilaku maka semakin rendah pula produktivitas kerja.

Penelitian ini mendukung teori yang dikemukakan oleh Sunyoto (2012) bahwa faktor-faktor yang mempengaruhi produktivitas kerja adalah pengetahuan, keterampilan, kemampuan, sikap dan perilaku.

Hasil penelitian ini dinyatakan sesuai dengan penelitian terdahulu dari Supriyanto (2012) yang menyatakan bahwa pengetahuan (knowledge), keterampilan (skills), kemampuan (abillities), sikap (attitude), dan perilaku (behaviors) berpengaruh signifikan terhadap produktivitas kerja.

\section{SIMPULAN}

Kesimpulan

1. Pengetahuan tidak mempunyai pengaruh terhadap produktivitas kerja karyawan PT. Multi Terminal Indonesia.

2. Keterampilan tidak mempunyai pengaruh terhadap produktivitas kerja karyawan PT. Multi Terminal Indonesia.

3. Kemampuan tidak mempunyai pengaruh terhadap produktivitas kerja karyawan PT. Multi Terminal Indonesia.

4. Sikap berpengaruh terhadap produktivitas kerja karyawan PT. Multi Terminal Indonesia.
5. Perilaku tidak mempunyai pengaruh terhadap produktivitas kerja karyawan PT. Multi Terminal Indonesia.

6. Pengetahuan, keterampilan, kemampuan, sikap, dan perilaku secara bersama-sama berpengaruh terhadap produktivitas kerja karyawan PT. Multi Terminal Indonesia.

Saran. Saran untuk penelitian yang

akan datang :

1. Saran untuk penelitian mendatang, bagi peneliti lain diharapkan memperhatikan faktor-faktor yang mempengaruhi produktivitas kerja selain variabel pengetahuan, keterampilan, kemampuan, sikap dan perilaku. Hal ini mengingat bahwa variabel pengetahuan, keterampilan, kemampuan, sikap dan perilaku hanya dapat menjelaskan produktivitas kerja sebesar $63,6 \%$ yang artinya masih terdapat $36,4 \%$ faktor-faktor lain yang mempengaruhi produktivitas kerja selain variabel tersebut. Penelitian yang akan datang bisa mengacu pada kerangka teori Prihatin, Hasan dan Yanti (2019) dengan variabel bebas komunikasi dan konflik, serta kerangka teoritis dari Simanjuntak dalam Sutrisno (2009) dengan variabel pelatihan, mental dan kemampuan fisik karywan, hubungan antara atasan dan bawahan.

2. Sampel (responden) dalam penelitian ini sangat terbatas karena jumlah dan ruang lingkup karyawan perusahaan yang tidak begitu besar sehingga relatif tidak bisa digeneralisasi untuk populasi yang lebih luas. Penelitian mendatang di harapkan dapat menggunakan sampel secara lebih besar dan luas agar diperoleh hasil penelitian yang lebih baik, lebih bisa di generalisasi, bisa memberikan gambaran yang lebih real tentang produktivitas karyawan. 


\section{DAFTAR PUSTAKA}

Ambar, Teguh Sulistiyani dan Rosidah, Manajemen Sumber Daya Manusia, (Yogyakarta: Graha Ilmu). 2009.

Anoraga, Pandji. (2004). Manajemen Bisnis. Jakarta:Rineka Cipta.

Amarsyah. Identifikasi Faktor - Faktor yang Mempengaruhi Produktivitas SDM Studi Kasus Pada Karyawan Bank BTN Syariah Malang. Jurnal. ISSN 0853-5167

Bambang Supomo, dan Indriantoro, Nur, 2009, Metodologi Penelitian Bisnis untuk Akuntansi dan Manajemen, Edisi Pertama, BPFE, Yogyakarta.

Eko Wahyono. 2015. Faktor - Faktor yang Mempengaruhi Produktivitas Studi Pada Karyawan Bagian Produksi PT. Nayati Inonesia)

Fendi Atmoko. 2016. Pengaruh Knowledge, Skills, Abilities, Attitude dan Behaviors Terhadap Produktivitas Kerja Studi Pada Karyawan Bagian Produksi PT. Sango Indonesia di Semarang.

Sedarmayanti. 2009. Sumber Daya Manusia dan Produktivitas Kerja. Bandung:CV MandarMaju

Gomes, Faustino Cardoso. 2003/2013. Manajemen Sumber Daya Manusia. Edisi Kedua. Penerbit Andi Offset, Yogyakarta.

Husein Umar. 2007, Metode Penelitian Untuk Skripsi Dan Tesis Bisnis, Jakarta: PT. Raja Grafindo Persada

Iswandi Idris. 2016. Produktivitas Kerja Karyawan Perbankan di Kota Medan.
Jayantini. Suwendra dan Susila. Faktor-Faktor yang Mempengaruhi Produktivitas Pada UD Wahyu Artha di Desa Menyali Kabupaten Buleleng. Jurnal

Malayu S.P. Hasibuan, (2007), Manajemen Sumber Daya Manusia, (Ed Revisi 9), Jakarta:PT. Bumi Aksara.

Notoatmodjo S. 2010. Ilmu Perilaku Kesehatan. Jakarta: PT Rineka Cipta.

Notoatmodjo S. 2012. Promosi Kesehatan dan Perilaku Kesehatan. Jakarta:Rineka Cipta.

Prihatin. Hasan dan Yanti. Pengaruh Komunikasi dan Konflik Terhadap Produktivitas Kerja Karyawan Pada PT. Pinus Merah Abadi Cabang Padang. Jurnal. ISSN 2407-6565

Robbins, Stephen P, 2003. Perilaku Organisasi, Jilid 2, PT. Indeks Kelompok. Gramedia, Jakarta.

Sedarmayanti. (2001). Sumber Daya Manusia dan Produktivitas Kerja. Jakarta:Mandar Maju

Sugiyono. (2016). Metode Penelitian Kuantitatif, Kualitatif dan R\&D. Bandung: PT Alfabet.

Sutrisno. 2009. Manajemen Sumber Daya Manusia. Jakarta:Prenadamedia Group

Supriyanto. 2012. Faktor - Faktor yang Mempengaruhi Produktivitas Studi Pada Karyawan Bagian Produksi PT. Nusantara Building Industries.

Sunyoto. 2013. Manajemen Sumber Daya Manusia. Jakarta:Caps.

Wibowo. 2007. Manajemen Kinerja. Edisi Kedua. Penerbit PT. Raja Grafindo Persada. Jakarta. 